\title{
The Immanent Critique and the Natural Rights Theory
}

In his contribution to the discussion of Marx's concept of critique and method of presentation, or critique and exposition [Kritik und Darstellung], Georg Lohmann ${ }^{1}$ explicated different levels or principles of critique in Marx's Capital and his critique of political economy in general. According to Lohmann, there is a fundamental difference between two principles of critique in Marx's Capital - the immanent and the transcending critique. The first form of critique is called immanent because bourgeois society is criticised with its own normative standards. The equality and freedom of the commodity producers is shown to be a mere appearance [reiner Schein] of the surface of that society, the sphere of commodity circulation preventing the exploitation of surplus value and surplus product from becoming visible. The title of property to the products of labour is not, in fact, as thought by classical political economy, based on one's own labour, but rather, on the contrary, is based on the appropriation of alien labour and its products. The right to private property is nevertheless, even in a bourgeois society, legitimated by the right to one's own labour and its products. The second form of critique is based on the experiences and the normative standards of those living under capitalism. Its standards and norms are those of the participants, actual social movements and forces of resistance. It takes its standards and principles from the arguments and declarations of the actual movement of emancipation under capitalism.

Only the immanent critique can be presented systematically and conceptually [begrifflich]; the transcending critique presupposes a form of presentation that is fragmentary and narrative-based. Marx's combination of presentation and critique in Capital follows the principle of immanent critique, whereas the elements of transcending critique are embedded as fragments in the presentation and in the so-called historiographic narrative parts of Capital.

Basically, the immanent critique is a critique of the fundamental suppositions of the modem natural rights theory as presented especially by John Locke and classical political economy with Adam Smith and David Ricardo as its leading representatives. Lohmann did not notice that even the transcending

1 Lohmann 1980. 
critique does, in a specific manner, criticise the basic legitimatory argument of the scientific self-understanding of the bourgeois society, vis-à-vis the possibility of human existence and the general well-being of the individual, including the wage worker, as a product of the accumulation of capital. It can be argued that Marx was thus implicitly criticising the fundamental legitimatory argument of classical political economy, according to which the economic laws, while functioning 'invisibly', behind the backs of private subjects, guarantee 'the greatest happiness of the greatest number'. Marx's critique, as presented most systematically in the chapter in Capital on the general law of capitalist accumulation, was later to become an essential and important part of the theory of capitalism of the Second International Marxism, which emphasised the growing misery of the working class in capitalism as an essential element of its theory of revolution.

In the beginning of his article, Lohmann presented two 'programmatic theses' about the systematic structure of Capital:

The systematisation of the critique of political economy can only be identified by the specific relationship between both types of critique. Accordingly, this critique of political economy means thorough-going criticism, that is to say, any interpretations that seek to extract a 'positive theory' from it, or understand it in that manner as a whole [sie als ganz so versteht], will go astray. ${ }^{2}$

One of the problems in interpreting the conceptual or theoretical structure of Marx's presentation in Capital is the methodological demand of uniting presentation and critique. ${ }^{3}$ Marx's presentation in this respect followed Hegel's well-known dictum, according to which the presentation includes the critique of the object presented. When something is conceptually comprehended, it is related to its very idea or concept [Idee oder Begriff]. The critical presentation is identical to bringing something to its concept of essence [wesenmässiger Begriff]. Comprehending thus includes critique, or rather it means judging the perfection of something or its correspondence to its concept. ${ }^{4}$

The main problem in Hegel's Logic, according to Lohmann, is that Hegel had to affirm in the presentation that which is negated in the critique. ${ }^{5}$ Following

2 Lohmann 1980, p. 237.

3 Ibid; cf. Marx 1974-2004n, p. 270.

4 Lohmann 1980, p. 240.

5 In this respect, Lohmann followed Theunissen's interpretation: 'Insofar as it is critique, Hegel's logic must affirm in its presentation what it actually negates' (Theunissen 1978, p. 88). 
Theunissen in his interpretation of Hegel's Wissenschaft der Logik, Lohmann made the following distinction between presentation and critique in Hegel's Logic: the presentation aims at the truth explicated as communicative freedom, the critique has falsehood as its object; the falsehood is understood, first, as not yet truth, and second, as totally false, as appearance [Schein]. ${ }^{6}$ Such a combination of presentation and critique is only possible when the standard of critique is included in the object of presentation. Such a critique is, therefore, characterised as immanent.

The object of Marx's presentation was the inner relation of bourgeois society. It had to be presented in such a manner that it included its necessary form of appearance [Schein] without being reduced to a mere appearancelikeness [Scheinhaftigkeit] - the fate of the vulgar economy as criticised by Marx. According to Lohmann, the constitution of this inner relation or order of bourgeois society is the classical theme of the modern natural rights theory (Hobbes, Locke, Rousseau). The systematic starting point for all of these modern conceptions is the concept of self-preservation or survival. ${ }^{7}$

The starting point for Locke's conception of the state of nature is the selfpreservation of the individual. Every individual has a right to self-preservation by using the necessary means of support. However, she or he is entitled to these products only so long as her or his own self-preservation does not endanger the self-preservation of others. The appropriation of the products of nature is mediated by labour. Just as every person is the sole owner of their own body, so they are the owner of the labour of their body and of the work of their hands. The products are freed from the state of nature by mixing labour with them so that something of the worker's own is added to them. From this thesis two further conclusions are drawn. These main axioms of Locke's natural rights doctrine are: (1) only labour can create a title to property; and (2) the different values of objects are based on labour used in appropriating them from the original state of nature.

Both the freedom and the self-preservation of the individual are thought to be secured by the natural right to private property. It furthermore secures the autonomy and independence of the individual. Under such circumstances, the property of another individual can only be appropriated by mutual consent through exchange of goods. The original rules and conditions prevailing in the original state of nature are, however, endangered by the introduction of durable goods (gold and silver). Once common consent has been reached, money

6 Lohmann 1980, p. 240; cf. Theunissen 1978, p. 87.

7 Lohmann 1980, pp. 242-3. 
may be used as a means of exchanging goods. In the original state of nature, nobody is allowed to own more than they or their dependants can dispose of privately. Thus, the tacit consent of the participants to introduce money into relations of barter threatens to unbalance the relation in the first state of nature characterised by the non-existence of money by encouraging a desire to appropriate more than is privately consumed. The accumulation of money capital and landed property made possible by the introduction of money presented by durable goods endangers everybody's natural right to private property and self-preservation, and the corresponding rights of freedom and equality. To guarantee these rights, Locke postulated a social contract constituting a state power. $^{8}$

According to Lohmann, the reinterpretation of the state of nature by the post-Lockean political economy further harmonised the Lockean concept by introducing the conception of a commercial or bourgeois society, the functioning of which is governed by immanent economic laws (invisibly) guaranteeing the realisation of the common interest of commodity producers. At the same time, the principles of Locke's state of nature remain valid even for this 'natural society' (freedom of the individual, the rightful appropriation of property by means of one's own labour and mutual exchange, and the equality of every individual as private property owner). ${ }^{9}$

Marx characterised the 'exchange of exchange values' (commodities) as the 'productive, real basis of all freedom and equality'. ${ }^{10}$ For Marx, the relation of exchange did not, however, constitute the inner relation of bourgeois society. Very generally speaking, Marx's critique of natural rights theory and political economy, according to Lohmann, was concentrated on the following idea: the real inner relation has to be sought in the relation of appropriation, i.e. production. In classical political economy, this inner relation is analysed as the determination of value by labour time; the value of commodities, which makes the exchange of commodities possible and is the integrative aspect of the constitution of society, is reduced to its immanent genesis, labour time. However, this reduction is valid and possible only under the conditions postulated by the natural rights theory. At the same time, the relations of exchange prevent the relations of production from appearing as the 'truly general' inner relation of society; value appears in a specific value form. ${ }^{11}$

\footnotetext{
8 Lohmann 1980, p. 244.

9 Lohmann 1980, pp. 244-5.

$10 \quad$ Marx 1973, p. 245.

11 Lohmann 1980, p. 246.
} 
According to Lohmann, in his critique of political economy Marx was interested in this very difference between the integrative and genetic aspects of the constitution of bourgeois society. He found the classical political economy praiseworthy because of its analysis of the constitution of bourgeois society (hence, its classicity), but criticised it for its lack of comprehension of the relation between the integrative and genetic aspects of society:

In this way it [classical political economy] conforms with the Lockean conception of the self-understanding of bourgeois society; the integrative aspect of the constitution of bourgeois society [the exchange of commodities] appears to be the only one that produces social cohesion [Zusammenhang] whereas the genetic aspect [appropriation of one's own labour] merely appears as a precondition of this, which belongs to the domain of the private sphere. ${ }^{2}$

Marx's presentation was by nature immanent while understanding its object from the perspective of the appearing and appeared relation, and it consequently followed the process of the constitution of its object. The immanent presentation was systematic in structure. It begins with the abstract and conceptual image of the whole and develops this image during the course of presentation into a concrete and differentiated thought totality [konkreter und differenzierter Gedankentotalität]. While doing this, the presentation presupposes nothing more than the bourgeois self-understanding does: the whole is only a realisation of the principles of the Lockean state of nature. Thus, the normative demands of freedom and equality are simultaneously presupposed, the demands which are claimed to be realised by society. In following this process of constitution, the realisation of the promise of freedom and equality is criticised. ${ }^{13}$

The immanent critique thus finds the standards of its critique in the very object of its study. It can formally 'take over' the normative standards of bourgeois society as explicated in the classical manifestation of its self-understanding, namely, classical political economy. These normative standards are formal principles of freedom and equality, and the right to private property based on one's own labour. In classical political economy, these standards are supposed to be universally valid, that is, they are meant to exist for all members of society. The task of the immanent critique is, first, to prove the inadequacy and

\footnotetext{
12 Ibid.

13 Lohmann 1980, p. 247.
} 
formal character of these normative standards, and second, to reveal the selfcontradictory nature of the system, through which the system is shown to be determined as a negative totality; in other words, it does not fulfil its own principles, which is equivalent to it being untrue. The immanent critique has now reached the point where it no longer 'understands' its object. It becomes evident that the whole object is in contradiction to its own normative standards and consequently it can no longer be measured with these standards. ${ }^{14}$ Only when it is possible to show that the standard of the immanent critique is a necessary standard of the exchange of commodities realised as the formal freedom and equality of every individual in bourgeois society can the inadequacy of the standard be proved.

In Theory and Practice [Theorie und Praxis], published in 1967, Jürgen Habermas pointed out the close affinity between Marx's critique and the natural rights theory. As the legitimate heir to natural law theory, political economy proved that the economic laws of society guarantee the realisation of the natural rights of humanity. In classical political economy, the natural laws of society are supposed to fulfil the common interests of human beings. In proving that the free intercourse of the private property owners, in fact, excluded the mutual enjoyment of personal autonomy by all individuals, Marx also proved that the general laws of bourgeois society were devoid of the supposed economic righteousness: 'The interests of the bourgeois can then no longer be identified with those of all citizens in bourgeois society'.15

All Marx had to do was confront the liberal construction of the natural rights theory with the development of the same society in order to argue with the bourgeois revolution. In philosophically producing a concept of itself, the bourgeois revolution could be criticised economically and taken at face value. Consequently, Marx understood the bourgeois revolution as the emancipation solely of the bourgeoisie, and not that of humanity. People are recognised by law as free and equal persons but, at the same time, they are under the natural-born [naturwüchsig] relations of an exchange society:

The political revolution resolves civil life into its component parts, without revolutionizing these components themselves or subjecting them to criticism. It regards civil society, the world of needs, labor, private interests, civil law, as the basis of its existence, as a precondition not requiring further substantiation and therefore as its natural basis. ${ }^{16}$

\footnotetext{
14 Lohmann 1980, p. 248.

15 Habermas 1979, p. 111.

16 Marx 1974-2004a, p. 167; cf. Habermas 1979, pp. 112-22.
} 
By analogy, Lohmann's analysis of the immanent critique in Marx's Capital was based on the idea of the formal nature of the principles of freedom and equality, which does not take into account the real basis of the constitution of the bourgeois society:

It is this dominance of mediating property that specifically restricts the integrative norms of freedom and equality. These are, in terms of their validity [ihrer Geltung nach] formal and generic, however are in fact tied to the substantive condition [inhaltliche Bedingung] of private property. They are therefore abstract norms of freedom and equality that are only valid because they are detached from one's own concrete individuality and that of others. ${ }^{17}$

Thus, freedom and equality are formal principles having validity only in the sphere of commodity circulation. The production process as the genetic constitutive process of society is based on the appropriation of surplus value, which is in contradiction with the constituting principles of bourgeois society as postulated by natural law.

The structure of the first book of Marx's Capital can now be interpreted in light of the distinction between the immanent and transcending critique; the immanent presentation ends with chapter 22, after which there are two more chapters (even though there are elements of transcending critique in earlier chapters too). At the end of the immanent presentation, the object is presented in its totality, as the process of reproduction of capital. On the one hand, capital is shown to be reproducing its own preconditions; the relation between capital and wage labour is continuously reproduced. Capital no longer needs any external historical conditions. On the other hand, the natural rights theory, supposing that a right to property must be based exclusively on the appropriation of the products of one's own labour and the exchange of equals, is challenged to defend its legitimatory basis; the only possibility to legitimate capital would be to prove that capital is, at least originally or historically, the result of capitalists' own labour. At this point, in order to legitimate itself capital must refer to its historical origins and, consequently, a historical presentation of the coming into being of capital is required. And historical analysis must also enter Marx's critique of capital: 
Capital is forced by the systematisation of its own legitimisation to overstep its own highly particular circles; it has to present its historical genesis. At the point in the system of Capital where all history has seemingly come to an end, it re-emerges in relation to the entire system ... Now the immanent critique effectively has its object where it wants it. It must present itself as an object that has developed historically [historisch gewordener Objekt] - and must do so under justificatory points of view [Rechtfertigungsgesichtspunkten] - after its normative self-contradictoriness has already indicated that it is a self-sublating [selbstaufhebend] object. ${ }^{18}$

Lohmann's conception of immanent and transcending critique was inspired by Karl Korsch's discussion of the different modes of critique in Marx's political economy ${ }^{19}$ Of the three different modes of critique formulated by Korsch transcendent, immanent and transcendental [transzendent, immanent und transzendentale Kritik] - the transcendent mode of critique most resembles Lohmann's concept of transcending critique:

Marx's critique is transcendent, really going beyond the boundaries of economics in those numerous passages - less prominent in scope yet important in content - where Marx, after pursuing political economy from the propositions postulated in its classical period through to their ultimate theoretical consequences, eventually bursts [through] the framework of economic theory itself and proceeds to a directly historical and social presentation of the development of the bourgeois mode of production and of the real contradictions concealed behind the two economic categories of 'capital' and 'labour' and of the struggle of the social classes. $^{20}$

In Korsch's conception, there was, however, supposed to be a strong parallelism between the development of Marxist theory and proletarian class movement: "The emergence of Marxist theory is, in Hegelian-Marxist terms, only the "other side" of the emergence of the real proletarian movement. ${ }^{21}$ As a phenomenon parallel to a social movement, Marxism is not only a critical theory of bourgeois society, but at the same time a theory of the proletarian revolution, in a rather

\footnotetext{
18 Lohmann 1980, pp. 280-1.

19 Lohmann 1980, p. 289, n. 6.

$20 \quad$ Korsch 1967, p. 220.

21 Korsch 1970, p. 42.
} 
straightforward way. ${ }^{22}$ Marx's critique of the bourgeois economy is based on the standpoint of the proletariat [Standpunkt des Proletariats] as the only class that is not interested in the preservation and legitimation of the bourgeois conceptions. $^{23}$

The transcending critique as explicated by Lohmann can be interpreted as being concerned with the consequences of development of capitalist society for the participants or individuals concerned. The transcending critique has to do with the normative standards of the participants. It introduces into the discussion the fate of labouring people (or the lot of the working class); the standard of the transcending critique has something to do with the experiences and also the opposition and actual resistance of the participants. The elements of transcending critique can be found in the historiographic paragraphs in Marx's Capital:

In their general form the passages show the historically recordable effects of the development of capital on the 'fate' of the people, especially the working class. They show the formal subsumption of pre-capitalist ways of working and living to the dominance of capital, the workers' acts of resistance and struggles for a life that is appropriate to their demands, but also the formation of their living processes and conditions. The immediate object of the presentation is, generally speaking, the historical contexts of people's lives [Lebenszusammenhänge der Menschen] under capitalism. $^{24}$

These passages characterise a horizon of universal history in the light of which the historical nature and limits of the capitalist mode of production become visible - and in them the object of immanent critique is transcended. The function of the transcending critique, according to Lohmann, is to justify the standard of immanent critique from a 'broader horizon':

The task of the critical aspect of the transcending critique is to prune the universal claims of the natural-rights (Lockean) self-understanding of bourgeois society. For this the transcending critique requires a benchmark, the strongest version of which is, for me, implied in the historiographical passages of Capital. ${ }^{25}$

\footnotetext{
22 Korsch 1967, p. 56; Korsch 1970, p. 82; see also Schanz 1974, pp. 39-42.

23 Korsch 1971, p. 138.

24 Lohmann 1980, p. 259.

25 Lohmann 1980, pp. 254-5.
} 
In the transcending critique, the relation between presentation and critique [Darstellung und Kritik] is different from that of immanent critique; the critical moment is the dominating one. A more important problem, however, is the fact that transcending critique cannot be embedded in the systematic, conceptual presentation in the same way that immanent critique necessarily is. Out of necessity, it is of a fragmentary and narrativistic character. In this sense, it can be compared with the positive philosophy of Schelling. ${ }^{26}$

The comparison with Schelling, however, should be taken cautiously. In his dissertation, Marx had explicitly criticised such a 'positive philosophy of reality'. The 'true immediacy' [Wahre Unmittelbarkeit] had been used as a critical point by all the 'young' Hegelians; the reality beyond reason is set against the infinite power of reason. The narrative form of Marx's transcending critique and its standards can be explicated too:

What cannot be theoretically appropriated with the immanent conceptuality of the capitalist-bourgeois self-understanding, i.e. what cannot be immanently presented systematically, is given over to a narrative manner of representation, which however is also accessible to a sensible explication. ${ }^{27}$

Lohmann's explication of Marx's two forms of critique is convincing in itself. However, there are at least three problematic questions connected with Lohmann's interpretation of Marx's critique of political economy. Some problems arise from the fact that his interpretation was influenced by Habermas's dual conception of 'system' and 'lifeworld' [Lebenswelt], even though Lohmann was at the same time explicitly criticising Habermas's conception of the normative standards valid in the lifeworld. ${ }^{28}$

First, Lohmann can be criticised for forgetting Marx's presentation of capitalist society as a negative totality in another sense. Fulda emphasised that Marx's critique of political economy is a theory of a catastrophe in a specific sense. ${ }^{29}$ Capital is understood by Marx to be a self-contradictory principle; the reproduction of capital is continuously faced by the limits set by the very process of value expansion. While increasing the productivity of labour and

\footnotetext{
26 Lohmann 1980, p. 26o; cf. Theunissen 1976.

27 Lohmann 1980, p. 261.

28 Habermas 1981.

29 Fulda 1978, pp. 194-5.
} 
relative surplus value, capital is all the more getting rid of its own basis of value expansion, namely, living labour power. This conception finds its clearest expression in Marx's analysis of the development of crises in capitalism and his law of the falling rate of profit:

But the main thing about their horror of the falling rate of profit is the feeling that capitalist production meets in the development of its productive forces a barrier which has nothing to do with the production of wealth as such; and this peculiar barrier testifies to the limitations and to the merely historical, transitory character of the capitalist mode of production; testifies that for the production of wealth, it is not an absolute mode, moreover, that at a certain stage it rather conflicts with its further development. ${ }^{30}$

The element of crisis is a continuous and permanent structural moment in capitalism - and in the critique of political economy. It determines capital as 'negative' - as pointed out by Stapelfeldt. The possibility of crises or disharmony is already present in the duality of abstract and concrete labour, and the dual character of commodity as both value and use value runs through the whole of Marx's presentation and defines the presentation as critique.

Secondly, the problem of the fetish character of the relations of commodity producers and the reification of social relations does not, in fact, fit very well into Lohmann's interpretation, even though he does discuss the problem of the reciprocal relations of indifference between private producers. The main problem of Lohmann's interpretation, in this respect, is connected with the Habermasian concept of lifeworld.

The mutual indifference characteristic of the relations between private producers [Gleichgültigkeitsverhältnisse] is based, according to Lohmann, on abstract labour. This indifference between private producers culminates in the indifference in the self-understanding of the owners of labour power. The relation of indifference is an example of structural domination because its causes are not manifest but hidden. However, Marx was - and this interpretation shows the close affinity of Lohmann's conception to that of Habermas - too harmless in his understanding of the indifferent relations because he understood human action exclusively in terms of goal-oriented, productive or instrumental action: 
The one-sided formulation of the fundamental conception of activity [Handlung], which can understand activity only as productive-concrete activity, comes back to roost in an underestimation of the extent of indifference that is provided by a reduction to abstract labour. ${ }^{31}$

The problem of the relation of indifference between actors was solved by Marx in terms of reification and the fetish character of the commodity: social relations take the form of relations between things. Money is a clear indicator of this indifference. Lohmann criticised the Marxian understanding of the fetish character because Marx was, at his best, only able to criticise the world of work (formal and real subsumption of work), but not the wider subsumption of the whole lifeworld by capital. A system integration based on indifference remains unstable as long as the ability to work has not taken the commodity form of labour power and the relations of the whole lifeworld take on the character of indifference:

With this, further indifference-phenomena come into the focus of the analysis, which concern the relation to others and the behaviour of those labouring between each other [sich-zu-sich]. These self-relations of the owner of labour power, characterised by indifference, which express a self-reification of their own and their common life, bring about further indifference-phenomena which go beyond the world of work ... encroaching upon the historical-social lifeworld of people. ${ }^{32}$

According to Lohmann's critique, Marx's conceptualisation of the lifeworld remains inadequate and undetermined:

From the standpoint of those subsumed, he can only insufficiently grasp in a conceptual way those processes of subsumption for which he, seen from the system, develops the concepts of the 'formal and real subsumption' for the formation of the working world and the historical-social lifeworlds ... In this the world of work is most clearly grasped, because an Aristotelian-Hegelian terminology of work and life is placed underneath it as a contrasting foil. ${ }^{33}$

$31 \quad$ Lohmann 1980, p. 271.

32 Lohmann 1980, p. 272.

33 Lohmann 1980, p. 277; cf. Lohmann 1984. 
In Marx's analyses, the lifeworld does remain conceptually undetermined. Therefore, it cannot oppose the subsumption by capital, either conceptually or in principle. This is the main reason why Marx's conception of transcending critique presupposes a specific form of presentation of its own. The presentation cannot, however, be theoretical and conceptual, but descriptive and argumentative. Its further explication would require a conceptual presentation of the historical-social lifeworld, and would thus overstep the limits of Marx's conceptualisation: "The explication of the content of the "historical considerations" as the presentation of historical-social lifeworlds must therefore go beyond Marx's conceptual framework. ${ }^{34}$

Lohmann did not, however, see Marx's concepts of the fetish character of commodity and the reification of social relations as a critical answer to the problem of the autonomy of the individual and the creatability and producibility of history as formulated by the philosophy of history of the Enlightenment and classical political economy. Marx solved the problem of the 'invisible hand' (Smith) or 'nature's purpose' [Naturabsicht] (Kant) by showing how social relations act as an independent and objectified alien power in relation to the acting individuals and are, at the same time, an objectification of their social labour or productive activity. Marx criticised the 'teleology of bourgeois society'. In his analysis, the historical teleology is not in need of a metaphysical explanation even though Marx used metaphorical expressions in characterising the inversion of social relations. ${ }^{35}$

The problem of the fetish character of social relations is important from the point of view of the interpretation of the Second International Marxism too, because the subsumption of the lifeworld was in a way taken into account by the famous thesis of immiseration, whereas the problem of the alien character of social relations can be seen to form a contrary interpretation of Marx's revolutionary perspective. ${ }^{36}$

The third problem in Lohmann's interpretation is closely connected with the previous one. As already pointed out, Lohmann did not notice that even the mode of critique explicated by him as a transcending one is, in fact, an implicit critique of the basic presuppositions of Locke's natural rights theory and Adam Smith's classical political economy, albeit on a different level from the immanent critique. While emphasising the nature of transcending critique as introducing the perspective and critical standards of those living and struggling

34 Lohmann 1980, p. 278.

35 Kittsteiner 1980, p. 282.

36 Mohl 1981; for further discussion, see the concluding chapter. 
in capitalism, Lohmann did not pay attention to the fact that the discussion of the fate [Geschick] of wage workers in Capital is a direct comment on a central legitimatory argument of classical political economy. Lohmann was right in emphasising that the transcending critique 'develops ... only the reasons that can be detected factually-historically for a judgement on capital, ${ }^{37}$ but he was not necessarily right in emphasising that a further development of Marx's critical presentation - in the spirit of Marx - would require an explication of the critical standards present in the historical-social lifeworld of the participants:

A theoretical extrapolation of the normative criteria of the transcending critique must refer back to this historical-moral self-interpretation of the participants in the historical-social lifeworlds. ${ }^{38}$

One of the main arguments of the present study is that the critical standards characterised by Lohmann as transcending, which were presented by Marx in the chapter on the general law of accumulation in Capital, can be understood as a critique of the basic postulate of classical political economy and its predecessor, natural rights theory, concerning the increasing opulence and well-being of the greatest number of the members of bourgeois society as a consequence of private property and accumulation of capital.

The previous discussion has emphasised the indebtedness of Marx's critique and analysis of capitalism to his predecessors, the modern natural rights theoreticians and classical political economists; the standards of both immanent and transcending critique are claimed to be essentially taken over from them. ${ }^{39}$ Consequently, the following presentation will take up Marx's critique of the justification of appropriation and private property, as well as his critique of the normative principles of freedom and equality, and his discussion of the general law of accumulation and its consequences for the fate of the working class.

37 Lohmann 1980, p. 283.

38 Lohmann 1980, p. 282.

39 In analysing Marx's reception and critique of classical political economy and its predecessors, it should be recalled that Marx was reconstructing a history of a theory, the labour theory of value and the theory of surplus value. As a result, he read the works of classical political economy with a specific theoretical and systematic interest. Classical political economy was - in a specific sense - understood by Marx to be an adequate conceptual expression of the system of bourgeois society. The critique of the economic doctrine also provided a critique of bourgeois society: 'The work I am presently concerned with is a Critique of Economic Categories or, if you like, a critical exposé of the system of the bourgeois economy. It is at once an exposé and, by the same token, a critique of the system' (Marx 1974-2004n, p. 270). 